\title{
Producing value from Australia's vineyards: an ethnographic approach to 'the quality turn' in the Australian wine industry
}

\author{
David Raftery ${ }^{1}$
}

\begin{abstract}
This article provides a detailed ethnographic intervention to the phenomenon of value-added agriculture, a discourse that has attained several concrete forms in Australian wine industry policy, and which is routinely presented as a legitimate rural future in wider agricultural and social science research. The legal and policy architecture of 'Geographical Indications' purports to value the regional distinctiveness of agricultural areas, by creating legally-defined wine regions. Producers from these wine regions enjoy privileged access to the use of regional descriptors that apply to their products, and the constitution of such wine regions can also codify the relationships between this regional identity and concrete viticultural and winemaking practices. This article draws on ethnographic research within the Clare Valley region of South Australia, one of the first Australian wine regions to be formally constituted as a legal entity, to examine in close detail the relationships that this region's wine producers have with their own discrete areas of operation. These ethnographic illustrations highlight that the creation of economic value within the premium wine industry cannot be reduced to the technical aspects of viticulture and oenology, nor the legal and policy means by which relationships between products and land are codified. Rather, the nuanced social understandings of landscape that wine producers are consistently developing is a critical element of cultural and commercial infrastructure that affords any wine producer or grape grower the possibility of achieving monopolistic relationships over discrete vineyard areas and the wine that is produced from them. These social understandings have a specifically egalitarian character that acts as a hedge against the chronic uncertainties arising from the global economic environment in which premium wine industry is inescapably a part. This resistance to codification, I argue, is a productive space that constitutes a form of resilience against chronically unstable sets of commercial and environmental conditions.
\end{abstract}

Keywords: monopoly, regional rents, occupational discourse, intellectual property, Geographic Indications, Australian agrarian futures

\section{Résumé}

Cet article fournit une intervention ethnographique détaillée au phénomène de «l'agriculture à valeur ajoutée», un discours qui a atteint plusieurs formes concrètes dans l'industrie vinicole australienne. Dans les sciences agricoles et sociales il est systématiquement présenté comme un avenir rural légitime. L'architecture juridique et politique des «indications géographiques» a pour but de valoriser le caractère distinctif régional des zones agricoles, en créant des terroirs de vin légalement définis. Les producteurs de ces terroirs bénéficient d'un accès privilégié à l'utilisation des appellations qui s'appliquent à leurs vins, et la constitution de ces terroirs peut aussi codifier les relations entre cette identité régionale et les pratiques viticoles concrètes. Cet article s'appuie sur la recherche ethnographique dans le terroir de la vallée de la Clare en Australie-Méridionale, l'une des premières régions viticoles australiennes à être formellement constituée en personne morale pour examiner de près les relations que les producteurs de vin de cette région ont avec leurs propres territoires. Ces illustrations ethnographiques mettent en évidence que la création de valeur économique au sein de l'industrie viticole ne peut se réduire aux aspects techniques de la viticulture et de l'œnologie, ni aux moyens juridiques et politiques de codification des relations entre produits et terres. Au contraire, la compréhension sociale nuancée du paysage que les producteurs de vins développent est un élément essentiel de l'infrastructure culturelle et commerciale. Elle donne à tout viticulteur la possibilité

\footnotetext{
${ }^{1}$ Dr David Raftery is an anthropologist (PhD, Australian National University) currently employed in State government in Australia. Email: raftery "at" iinet.net.au. The research on which this article was based was conducted as part of doctoral studies in the School of Archaeology and Anthropology at the Australian National University (ANU). Special acknowledgment to Professor Francesca Merlan for her supervision and guidance. Doctoral study was supported by a School of Archaeology and Anthropology fieldwork grant and an ANU Graduate Research Scholarship. The author wishes to thank JPE editor, Simon Batterbury, and anonymous reviewers for their guidance.
} 
d'établir des relations monopolistiques sur les vignobles distincts et sur le vin. Ces compréhensions sociales ont un caractère spécifiquement égalitaire qui fournit une certaine sécurité contre les incertitudes chroniques découlant de l'environnement économique mondial dans lequel l'industrie du vin fonctionne. La résistance à la codification, je constat, offre une résilience contre l'instabilité chronique des conditions commerciales et environnementales.

Mots-clés: monopole, loyers régionaux, discours professionnel, propriété intellectuelle, Indications géographiques, futures agraires australiens

\section{Resumen}

Este artículo ofrece una detallada intervención etnográfica del fenómeno de la agricultura de valor agregado, un discurso que ha alcanzado numerosas formas concretas de las políticas en la industria vitivinícola australiana, la cual se presenta como el legítimo porvenir rural de una más amplia investigación en ciencias sociales y agrícolas. La arquitectura legal y de las políticas de las “denominaciones de origen” pretenden dar valor a la particularidad regional de las áreas agrícolas con la creación y definición legal de regiones productoras de vino. Los productores de estas regiones vitivinícolas disfrutan de un acceso privilegiado del uso de los descriptores que aplican para sus productos, y la constitución de dichas regiones puede también codificar las relaciones entre esta identidad regional y las prácticas de viticultura y elaboración del vino. A través de trabajo etnográfico en la región de Clare Valley al sur de Australia -una de las primeras regiones vitivinícolas del país constituidas como entidades oficiales-, este artículo examina a detalle la relación que tienen los productores regionales con sus distintas áreas de operación. Estos ejemplos etnográficos resaltan que la creación de valor económico dentro de la industria del vino de alta calidad no puede reducirse a los aspectos técnicos de la viticultura y enología. Tampoco a los medios legales y de políticas por los cuales las relaciones entre productos y la tierra están codificadas. Al contrario, los matices en la visión social del escenario que los productores vitícolas están constantemente desarrollando, es un elemento crítico de la infraestructura cultural y comercial que ofrece a cualquier productor de vino o de uva la posibilidad de desarrollar relaciones monopólicas sobre los propios viñedos y el vino que en estos se produce. Estas visiones sociales tienen un específico carácter igualitario que actúa como una cubierta contra las incertidumbres que constantemente surgen del ambiente económico global en que la industria del vino de calidad está irremediablemente involucrada. Argumento que esta resistencia a la codificación es un espacio productivo que constituye una forma de resiliencia contra las constantemente inestables condiciones comerciales y medioambientales.

Palabras clave: monopolio, rentas regionales, discurso de ocupación, propiedad intelectual, denominación de origen, futuro agrario australiano.

\section{Introduction}

The proposition that Australian agriculture faces a crisis in sustainability, is a thesis that has many adherents (Bjorkhaug and Richards 2008; Diamond 2005; Flannery 2008; Gray and Lawrence 2001; Lawrence and Vanclay 1994). The relative decline of agriculture's contribution to the Australian economy, and the degradation of the ecological and social resources upon which it ostensibly depends, have received much attention within social science and policy research (Alston 2004; Cocklin 2005; Lawrence 1987; Lawrence and Vanclay 1995; Lockie and Bourke 2001).

Australian agriculture faces a double challenge: on the one hand the transition to a global trading environment that has seen tariffs on Australian commodities removed but where the protectionist policies of other major producers have persisted, and on the other the chronic environmental challenges besetting agriculture. A diverse range of policy traditions have evolved to diagnose and address these challenges, and to chart the course of viable agricultural futures. These include a long tradition of drought policy (Askew and Sherval 2012; Botterill and Willhite 2005), extensive research into farming technologies (Hunt et al. 2012; Marsh and Pannell 2000), massive irrigation projects such as the Ord River Scheme that purport to increase the reach and scale of arable land (Head 1999), and a range of policies that focus on the production and marketing of higher-value beverages and food that has been characterised as the "quality turn" in agriculture (Goodman 2003). 
It is the last of these rural futures that is the direct concern of this article (Merlan and Raftery 2009: 1). In particular, I am concerned with one rendering of agriculture's quality turn: the premium wine industry. Premium wines are typically produced from specially-selected grapes that are cultivated on small landholdings, with minimal irrigation inputs, and are marketed in ways that stress the distinctive relationship between the product and its provenance, with the goal of attracting prices that are well beyond growing costs. Because the premium wine industry can be readily identified as a way off the agricultural treadmill of increased farm size, the cost-price squeeze and chronic environmental challenges, this industry occupies a privileged position in policy debates about agricultural viability (Diamond 2005; Lawrence 1987; Lawrence and Gray 2001; Lawrence and Vanclay 1994, 1995).

This article is divided into four parts. In the first, I detail the character of the particular economic challenge that fine wine production presents, before shifting focus to the recent Australian policy that has supported the development of a premium wine industry, in particular the legal codification of wine regions as 'Geographical Indications', where wine regions and the names that describe them are protected under Australian and international law. This has given Australian wines deepened access to international markets, whilst also requiring Australian wine regions to be self-consciously described and defined. The second section then concentrates closely on the regional environmental, historical and cultural attributes that underpinned the creation of the common legal identity of an Australian wine region, the Clare Valley Geographical Indication in South Australia, a legal identity that has provided a basis for the region's wine makers and grape growers to pursue pursuing distinctly monopolistic rents by producing wines that are inescapably from the Clare Valley. The third section probes more deeply into the everyday occupational knowledge and practices of the wine producers and grape growers within the Watervale area, a smaller location within the Clare Valley. This detailed ethnographic analysis underlines the deliberate attention that is devoted by wine producers to try and understand the import of the relationships between the physical environments in which they work, and the enterprise of premium wine production. This fine-grained focus on small areas of land, precise processes of production, and subtle seasonal effects, I argue, results in the formation of distinctive, monopolistic wine identities, which in itself is a critical means of mediating the inescapable local conditions of one's vineyard and a domestic and international wine market that has become progressively larger and more diffuse. In the concluding section of this article, I query to what extent the formal regulation of regional agricultural economies can underpin the creation of viable agricultural futures, like the premium wine industry, that Diamond identified as being so crucial to Australia's sustainable agricultural future (2005).

\section{The logic of premium wine production}

The commercial success of premium wine, wine that attracts prices well beyond basic growing and production costs, depends on the painstaking manual work of grape-growing, the application of highly tailored inputs in the winemaking process, and the cultivation of distinctive regional wine identities. It is an enterprise that is at once highly embedded in discrete physical habitats and enmeshed in global commercial networks. In fine wine production, the relationship between wine and its provenance is emphasized, and the different factors of its physical production such as soil, grape variety, labor practices, and micro-climate, critically determine the character and quality of the wine that is presented to market. The embedded character of this enterprise presents ready ethnographic opportunities, and the relationship between these factors needs to be interrogated to properly understand the form and extent of the niches within the wider wine industry that quality wine producers are seeking to create and occupy.

The difficulty of the fine wine challenge in Australia has been described (Simon 1966; Whittington 1997), and these challenges are constantly reprised by contemporary wine journalists (Halliday 2007a, 2007b; Keys 2006; Mattinson 2007), and winemakers themselves (Croser 2010). The chronic challenges associated with decreasing access to water and a changing climate have given greater urgency to the wine industry's efforts to focus more on premium production, to the point where its ongoing development is 
legitimately established as an Australian rural future (Garnaut 2008; Hardisty 2010; Merlan and Raftery 2009: 1).

The character of the relationship between the political imperatives that relate to agricultural production, and the agricultural communities that are central to this production, has been a focus of anthropological concern (Netting 1974). With notable exceptions however, scarce attention has been directed to the actual labor that contributes to the creation of quality wine (Perry et al. 1997; Warner 2007a,b). Within the political ecology field, Black (1990) has considered the relationship between agrarian strategies and environmental conditions in relation to vineyards, and Rainer (2016 a,b) shows how neoliberalism in Argentina provoked a shift to premium wine production in the Salta region. This article makes a key contribution to research on Australian agricultural futures, by offering a critical ethnographic elucidation of the challenges of creating economic value from an environment that offers up increasing environmental constraints and within a wine market that is increasingly competitive (Anderson 2003; Cox and Bridwell 2007; Rabobank 2015). Political ecology is well disposed to analyse these types of relationships (Watts 2000), but is yet to train attention on Australia's vineyards, despite Australia being the fourth largest wine exporter (ABS 2010).

Scant social scientific research exists that details the character of the Australian wine industry. The little research that exists focuses on disputes over the definition of wine regions (Banks and Sharpe 2006; Edmond 2006), and grower-winemaker relationships and grape growing styles in irrigated, non-premium wine areas such as the Riverland and Riverina (Mesiti and Vanclay 1996; Pritchard 1999). Given that industry bodies (Wine-Australia 2007), government research agencies (Sheales et al. 2006), winemakers themselves (Lofts 2010), and agricultural financiers (Rabobank 2015) habitually stress the importance of the Australian industry shifting its emphasis to higher-value production that creates recognisable, distinctive place-specific brands, there is an alarming neglect of the social relationships through which these goals might be achieved. This neglect stands in contrast to the contributions that anthropologists have made to understanding social and cultural transitions in the French wine industry (Barham 2003; Song Yoon 1975; Ulin 1996, 2002) and many other non-Australian agricultural settings (Bennett 1969; Barlett 1980; Gray 1996, 2009; Rainer 2016). This article interrogates the occupational discourse of winemakers and wine grape growers who work every day to not only produce wines for the premium market, but to understand the relationships between the application of their own skills and knowledge to the physical environments on which their businesses depend. As such, it is an ethnographic intervention in a well-developed set of policy agendas.

Within the wine industry and its surrounding policy architecture the ubiquitous terms premium, quality, and fine are often used interchangeably. These terms can be characterised as "keywords" (Williams 1976), in that they enable their users to assemble a range of diagnoses, aspirations and prescriptions that crystallise in business strategies and government policies that pertain to the wine industry's future. In the voluminous literature on quality-focused agricultural production (Neo 2011), the term quality denotes a high degree of human inputs including knowledge, manual agricultural skills, and constant monitoring (Stinner and House 1987) that are frequently set within complex regulatory fields (Perry et al. 1997). Yields in quality production regimes are routinely lower than regimes that rely on high chemical and mechanical and water inputs, but attract greater income per unit of production.

This very issue of quality versus quantity, or value versus volume, is one that has preoccupied winemakers and grape growers since wine became an item of religious and commercial significance (Unwin 1996), and it is a recurring tension in the wine sector. Andre Simon, a French wine scholar who surveyed Australia's industry in the 1960s, noted that "The vineyards of Australia may be divided into two main groups, the quality group and the quantity group" (Simon 1966: 3). Simon, like many that followed him (Allen 2010; Halliday and Johnson 1992: 17), stressed that a wine industry that was focused on loweryielding, higher priced vineyards that received more personalised attention, represented a challenging, but ultimately more viable future: 
The small vigneron is by no means doomed: he may and he will, we all hope, continue to tend his vineyards as all good vineyards must be tended, with the loving care that is the only truly intelligent care. The big firms will only be too happy to buy his grapes at a rewarding price because his grapes, with the loving care that is the only truly intelligent care will be better than those of their mammoth vineyards mechanically cultivated. (Simon 1966: xiii)

Since Simon's survey in 1966, Australia's wine industry has been marked by a stark contrast between its irrigated wine regions, and "the quality group" (Simon 1996: 3). ${ }^{2}$ In 2007, when my initial fieldwork commenced, $60 \%$ of Australian wine was produced in the irrigated Riverland regions at the junction of New South Wales, Victoria and South Australia, irrigated with water from the Murray and Darling Rivers. These irrigated regions have produced high volumes of reliable, generic wines in largely mechanised settings, whilst the non-irrigated wine regions are geared to producing lower volumes of wines that are more varied in style, taste and cost, and involve far greater manual input. It is wine from these irrigated Riverland regions that led the massive expansion in Australian exports to the UK and the USA, and that secured strong reputations for Australian wines as consistent, accessible and offering excellent value for money (Banks et al. 2007: 20). This success of this recent export strategy has faded dramatically since the over-supply of grapes that affected the 2005 and 2006 harvests, and the severe droughts of 2007 that resulted in the lowest yields per hectare since 1976 (Halliday 2007a). The reduction in commercial water allocations from the MurrayDarling river basin on which irrigated viticulture has depended have been enshrined in the legally enforceable Murray-Darling Basin Plan (Commonwealth of Australia 2012), reducing the comparative advantage once enjoyed by these regions over other New World producers like Chile, Argentina and South Africa.. The ten vintages from 2005-2006 through 2014-2015 demonstrate consistent national levels of total grape crush, wine production, and domestic sales.

James Halliday (2007a) predicted that that the Australian wine industry, because of increased international competition and the dearth of irrigated water, would need to shift more to quality-focused production to survive. In the period since my ethnographic field work was conducted, the national wine industry trend has moved in the direction of premium wine production (Figure 1). The 2016 vintage recorded a $14 \%$ increase in the average prices for wine grapes, the highest since 2009, and trend that was in part driven by an increase in the proportion of wine grapes sold that attracted price above AU\$1,500 (US\$1,151) per tonne.

\begin{tabular}{|c|c|c|c|c|c|}
\hline Year & $\begin{array}{c}\text { Crush 1000 } \\
\text { tonnes }\end{array}$ & $\begin{array}{c}\text { Production } \\
\text { Million litres }\end{array}$ & $\begin{array}{c}\text { Exports } \\
\text { Million litres }\end{array}$ & $\begin{array}{c}\text { Domestic sales } \\
\text { Million litres }\end{array}$ & $\begin{array}{c}\text { Total sales } \\
\text { Million litres }\end{array}$ \\
\hline $2005 / 06$ & 1902 & 1398 & 720 & 367 & 1169 \\
\hline $2006 / 07$ & 1397 & 947 & 780 & 388 & 1254 \\
\hline $2007 / 08$ & 1832 & 1242 & 690 & 373 & 1148 \\
\hline $2008 / 09$ & 1733 & 1172 & 734 & 383 & 1201 \\
\hline $2009 / 10$ & 1573 & 1127 & 759 & 396 & 1248 \\
\hline $2010 / 11$ & 1602 & 1100 & 714 & 393 & 1195 \\
\hline $2011 / 12$ & 1658 & 1211 & 703 & 389 & 1176 \\
\hline $2012 / 13$ & 1748 & 1219 & 687 & 385 & 1156 \\
\hline $2013 / 14$ & 1663 & 1186 & 681 & 388 & 1152 \\
\hline $2014 / 15$ & 1707 & 1191 & 710 & 386 & 1180 \\
\hline
\end{tabular}

Figure 1: National wine grape crush, wine production, domestic and export sales - 2005-2006 to $2014-2015$.

\footnotetext{
${ }^{2}$ Some $63 \%$ of Australia's wine and table grapes were produced on properties within the Murray-Darling basin (Murray Darling Basin Commission 2007).
} 
A comparison between the Clare Valley wine region, the site of my fieldwork, and the irrigated Murray Valley region on Victoria provides an apt illustration of the different registers of production (Figure 2). The Clare Valley uses nearly seventeen times less water than the Murray Valley, and attracts prices for grapes nearly three times as high for grapes.

\begin{tabular}{|c|c|c|c|c|c|c|}
\hline Region & $\begin{array}{c}\text { Wine grape } \\
\text { yields (ton } \\
\text { per hectare) }\end{array}$ & $\begin{array}{c}\text { Wine grape } \\
\text { prices (AU\$/US\$ } \\
\text { per tonne) }\end{array}$ & $\begin{array}{c}\text { Revenue } \\
\text { (AU\$/US\$ } \\
\text { per hectare) }\end{array}$ & $\begin{array}{c}\text { Revenue } \\
\text { (AU\$/US\$ } \$ \\
\text { per hectare) }\end{array}$ & $\begin{array}{c}\text { Water use } \\
\text { (Megalitre } \\
\text { per hectare) }\end{array}$ & $\begin{array}{c}\text { Operating } \\
\text { costs } \\
\text { (AU\$/US\$ } \\
\text { per } \\
\text { hectare) }\end{array}$ \\
\hline Clare Valley & $\begin{array}{c}4 \text { (red) } \\
5 \text { (white) }\end{array}$ & $1,721 / 1,198$ & $7,313 / 5,093$ & $7,313 / 5,093$ & 0.6 & $\begin{array}{c}6,144 / 4,27 \\
9\end{array}$ \\
\hline Murray Valley & 10 & $609 / 424$ & $10,631 / 7,404$ & $10,631 / 7,404$ & 10 & $\begin{array}{c}6,830 / 4,75 \\
7\end{array}$ \\
\hline
\end{tabular}

Figure 2: Comparison of a 'quality' and 'quantity' wine regions: the Clare Valley and Murray Valley. ${ }^{3}$

If the production of premium wine does promise a viable future for many of Australia's wine grape growers and winemakers, what exactly does this production consist of? On the one hand the production of wine employs key industrial agriculture techniques (Goody 1982); it uses mechanised equipment to cultivate, harvest and crush grapes, it requires the controlled preservation and fermentation of grape juice, and the organisation of complex transport and networks operate to market and distribute wine. Conversely, making fine wine also requires the relentless, manual attention to grape vines at specific vineyard sites, the painstaking production of wine that expresses the terroir of these sites, and much face-to-face promotion of wines. Such production is by definition small in volume, distinctive in style, and attracts higher unit prices.

The specific character of the vineyard that provides fruit to winemakers is seen as critical to a wine's particular quality. The soils, the vineyard aspect, the manner in which the vines were cultivated and allowed to ripen are central factors that quality wines seek to make explicit. In addition, the manner in which the juice from grapes is fermented, fined, bottled and aged is emphasised. Such a chain of production requires a great deal of manual, ongoing attention to the grape and wine, and a highly personalised understanding of local conditions. In short, quality wine is "embedded" in the social and physical environment from which it is wrought (Goodman 2003: 1). ${ }^{4}$

Brian Croser (2006), a prominent Australian winemaker and industry figure, offers this concise analysis of the logic of fine wine production:

The very attributes of fine wine production are antithetical to the branded commodity wine proposition. Unique, non-expandable sites with low yielding vines producing concentrated complex wine, varying in style and quality between vintages and between producers of the same varieties from the same region, are attributes impossible to reconcile with the standardised requirements of the branded commodity wine business. (Croser 2006: 14)

\footnotetext{
${ }^{3}$ Table constructed by the author from ABARE data, provided in Gordon (2004).

${ }^{4}$ Heller (2007) characterises such practices as techne, a craft, or practical application of art to particular vocational tasks. Polanyi (2001) provides much of the foundational discussions of the embeddedness of economics within social and environmental relationships.
} 
This logic of production is profoundly inconsistent with the production and marketing of generic commodity wines, which, Croser argues, can only be effected by the "supermarket oligopolies" that dominate the retail sector (2006: 16). The logic of fine wine production resists a standardization of practice that erases the evidence of place, seasonal variability and unique human inputs. Rather, the terroir of the vineyard site, and the specific labor imbued in the wine's production, are elevated in the identity of the wine. This logic has a monopolistic imperative in that a premium wine can only be produced from a particular place and season, and is the culmination of specific practices.

In the Australian wine sector, the state has played an active instrumental role in supporting and sanctioning the conditions under which the monopolistic potential of agricultural production can be realised by wine producers. Since 1993, in order for Australian wine producers to sell products that are explicitly identified with a geographic region, the Australian Wine and Brandy Act 1980 has required wine regions to be registered as Geographical Indications (GIs). These formal codifications of the relationship between wine and place are mandatory pre-conditions to selling place-labelled wine in the European Union, which remains Australia's major export market. This policy direction has been enabled through legislation that ensures that the relationship between a geographic region and marketable product is a commercial asset whose use is regulated.

It needs be stressed that this policy trajectory is contradicted and undermined by the expansionary imperatives that are consistently applied to the wine industry, in particular the tax concessions that have encouraged large-scale horticultural and viticultural plantings (Lacey and Watson 2004). These concessions have been critical in achieving the export volume goals set out in the 1996 wine industry document Strategy 2025 (annual sales of $\$ 4.5$ billion [US\$3.5bn] by 2025), which were reached a full 20 years ahead of the 2025 'deadline.' The difficulty of predicting the development of the wine industry, given the chronic variability of exchange rates, irrigation access, rainfall, credit and labor, let alone factors affecting the capacity of competing wine economies, is formidable. ${ }^{5}$ Unsurprisingly, persistent over-supply of wine and the corresponding decline in the value per litre of Australian wine sold both domestically and internationally, prompted the Winemakers Federation of Australia and the Australian Wine and Brandy Corporation (the national statutory authority that created by the AWBC Act) to revise their marketing goals and make growth in the value per litre of Australian wine central. Released in 2007, Directions to 2025 emphasised the construction of identifiable "wine personalities" as a key means through which this value growth is driven (Wine Australia 2007:14).

In practical terms, the registration of GIs has imposed a statutory requirement on regional wine producers to present such 'wine personalities.' GIs involve the collective identification and assertion of common regional attributes, and typically emphasize the ecological, climatic and historical factors that underpin a region's homogeneity as a wine landscape. The demonstration of these attributes is required to constitute a wine region as a legal fact, and in turn, as a commercial opportunity. This statutory imperative in large part enforces the logic of the premium wine strategy, a strategy identified by the wine industry itself as critical to the sector's viability (Rabobank 2015; Sheales 2006; WFA 1996; Wine Australia 2007). Whilst GIs are regulated by government, they can only be created to reflect existing regional characteristics.

GIs have been progressively applied to French agricultural products from as early as 1919 (Barham 2003; Heller 2006; Moran 1993b), and have been introduced to Australia since 1993 (Smart 2007). Moran (1993a: 272) identifies GIs as opportunities for agricultural communities to try to capture the economic rent of localities and regions, and to create differential rent through demarcating the areas of origin of specific agricultural products. In this sense the proliferation of GIs has sought to forestall the extreme commoditisation that threatens the viability of commercial wine production, where wine's provenance is reduced to irrelevance.

\footnotetext{
${ }^{5}$ See Wine Australia (2007) for Directions 2025 and Australian Wine Foundation (1996) for Strategy 2025.
} 
David Harvey (1982, 2002) has argued that the theory of monopoly rent can be applied to cultural and economic phenomena in late capitalism where commodity relationships are the dominant commercial form. ${ }^{6}$ Monopoly rent becomes possible when individuals or groups are able to exercise exclusive, monopolistic, or oligopolistic control over objects of trade that in turn can provides enduring income based on the special qualities that these objects acquire. The key to acquiring monopoly is that the objects of trade must be unique, such that no other individual or group can produce such items for the market (Harvey 2002: 2). Harvey directs this analysis to the wine industry, following Marx, who himself paid particular attention to the very phenomenon of prestigious vineyards being the source of monopolistic rents (1967: 774-775). In the case of fine wine, it is the uniqueness of the vineyard site, and the practices that are performed on it, which creates the foundation for the monopoly price that can be rent from the vineyard's produce, and which in turn enables the owners or controllers of such sites to continually invest in these sites, thus cementing their particularity (Harvey 2002: 3). Just what is involved in striving for such monopolies, in trying to secure such regional rents? These questions are answered in ethnographical detail in this article's next two sections, but some preliminary comments here help frame the Australian context.

The heavily structured hierarchies of the so-called Old World wine economies, in particular France, have received much attention in the social sciences (Barham 2002; Black and Ulin 2013; Demossier 2011; Garcia-Parpet 2008). Ulin (1996), for instance, provides a detailed ethno-historical account of the emergence of the Bordeaux wine region, demonstrating how over time the unique identities and commercial value of its wines, and the grapes that were crushed to produce them, have come to be expressed in terms of the soil and climate specific to that region. He charts the emerging pre-eminence of Bordeaux, and shows that the political and social relationships on which the production of this region's elite grands crus wines, as encapsulated in the elite chateaux where commercial wine producing enterprises are enduringly entwined with increasingly prestigious vineyard estates, were naturalized as cultural understandings of the relationship between soil, climate, and wine growing. This relationship is often expressed by the term terroir, a word that has no ready English translation, but that can be generally understood as referring to a small area or terrain, with a unique soil profile and microclimate (Wilson 1998). Precisely because soil and climate are readily associated with the immovability of nature, rather than the arbitrary contingencies of politics and commerce, powerful cultural symbols are created. Such symbolic constructions are not merely rhetorical, Ulin stresses, but have real impacts in terms of the classification of the specific terrain from which wine grapes are sourced (1996: 8), and the price that wines from these regions command. The terrain on which this region's wine grapes are grown and the specific practices of viticulture and vinification that the region's wines undergo (Barham 2002) become territory, in the sense described by Elden (2010). Simply put, what grapes can be grown where, and how grapes and wine can be produced, and the hierarchies of value that apply to different territories, are mapped in intricate geographic and operational detail, and these orders are publicly enforced.

But the Australian situation is very different. The formal constitution of wine regions as GIs was only enacted in the context of formal trade agreements with the European Union so that producers from identifiable regions, like the Clare Valley or the Barossa Valley, could sell wines under regional descriptors over which a monopolistic privilege was then asserted. In the Australian wine industry, the large (and lowerpriced) wine producers of the irrigated inland regions dominated Australia's wine exports, yet inscribed scant geographic specificity on this trade. The pursuit of monopolistic regional rents through Geographic Indications was more a disruptive than a hegemonic phenomenon. Whilst legislative and bureaucratic requirements do indeed apply to the formal constitution and regulation of the wine regions within Australia (Figure 3), the creation of these regions can only occur through the organising efforts of regionally-based grape growers and wine producers who are themselves required to demonstrate the homogeneity of their prospective wine region as set against other regions, and by reference to particular attributes that are discussed further in the next section. The legal codification of wine regions in Australia is perhaps better

\footnotetext{
${ }^{6}$ See also Chapters 5 and 11 in Harvey (1989) for a critical summary of Marx's theories of monopoly.
} 
understood as voluntarist action that purports to create conditions of rent within an industry that is increasingly global in reach.

\section{Securing regional rents: how the Clare Valley geographical indication was 'created'}

For Clare Valley winemakers, there is a strong imperative to create distinctive identities for themselves and the wines that they make, that in turn may be realised as enduring economic value. The environmental conditions that limit volumes of production in the Clare Valley: its small size, the lack of irrigated water, and topographical resistance to mechanisation, are strong constraints - but these same limits are cast as distinctive advantages. The manual skills that growers and winemakers bring to their enterprise, and the lack of technological uniformity that is imposed on viticultural production in the reckoning of producers, ensure that wines made in the Clare Valley can be readily distinguished from wines made elsewhere. Allowing this distinction to be expressed through the application of viticultural and winemaking skills, and elaborating this distinction in the marketing of wines are tasks that are approached with great (and costly) seriousness.

A distinctive aspect of the Clare region's wine industry is the sheer diversity of not only business models, and but also the ways in which the coordination of grape growing and winemaking occurs. There are fifty businesses ${ }^{7}$ based in the Clare Valley producing wine from the region's vineyards, with wine producers crushing volumes ranging between ten to 10,000 tonnes. Clare Valley wine producers demonstrate a host of business types: multinational joint-stock company, large private companies, small syndicates, a religious order and small and larger family enterprises. The diversity of these arrangements underscores the reality that there are numerous ways to produce fine wine and it cannot be reduced to a singular social formula.

What unites this disparate assembly of winemakers and wine grape growers is identification with 'quality' viticulture and winemaking. Clare Valley grapes and wines attract much higher prices than those from irrigated wine regions elsewhere, and receive much less irrigated water. This shared identity has been further consolidated through the legal codification, as a GI, of the Clare Valley wine region that encompasses the towns of Clare, Sevenhill, Auburn, Penwortham, Mintaro, Leasingham and Watervale. This has enabled winemakers from these areas to trade upon their regional identity and has ensured that only wines that are produced from Clare Valley grapes are marketable as Clare Valley wine. In Australia, the Australian Wine and Brandy Corporation Act 1980 is the legislation under which determinations of Australian GIs are made. A GI is an officially sanctioned description of a wine zone, region, or sub-region, the key purpose of which is to protect the use of the particular name associated with that region under international law. Zones are the largest defined areas, regions are encompassed by zones, and sub-regions are contained within regions. In 2015 there were 30 zones, 65 regions and 14 sub-regions registered in Australia (Wine Australia 2015) Some well-known Australian wine regions include the Barossa Valley, the Coonawarra, Margaret River, and the Hunter Valley.

Registration of a GI requires a joint application from at least five wine producers who, in aggregate, crush at least 500 tonnes of grapes from a region that contains a minimum of five fruit-bearing vineyards. Once established, the only requirement that attaches to a GI is that any wine produced from that area must conform to what is colloquially known as the '85-15 rule', which stipulates that a wine bearing the name of, say, the Clare Valley, must be made from not less than 85\% Clare Valley GI grapes.

\section{The Clare Valley Geographical Indication}

The Clare Valley region was one of the first Australian wine regions to be registered as a GI, and amongst the 50 wine producers and over 200 grape growers within this region. This status is uncontroversial. Members of the region's industry readily distinguish themselves from the grape growers and winemakers in irrigated wine regions like the Riverland, which have produced the generic, reliable, affordable wine that has

\footnotetext{
${ }^{7}$ These details reflect the status of the Clare Valley's wine producers at the conclusion of my field research, in 2008.
} 
dominated Australia's export markets, and overseas perceptions of Australian wines since the 1980s (Banks 2007: 16), and prestigious regions like the Barossa Valley that are nearby.

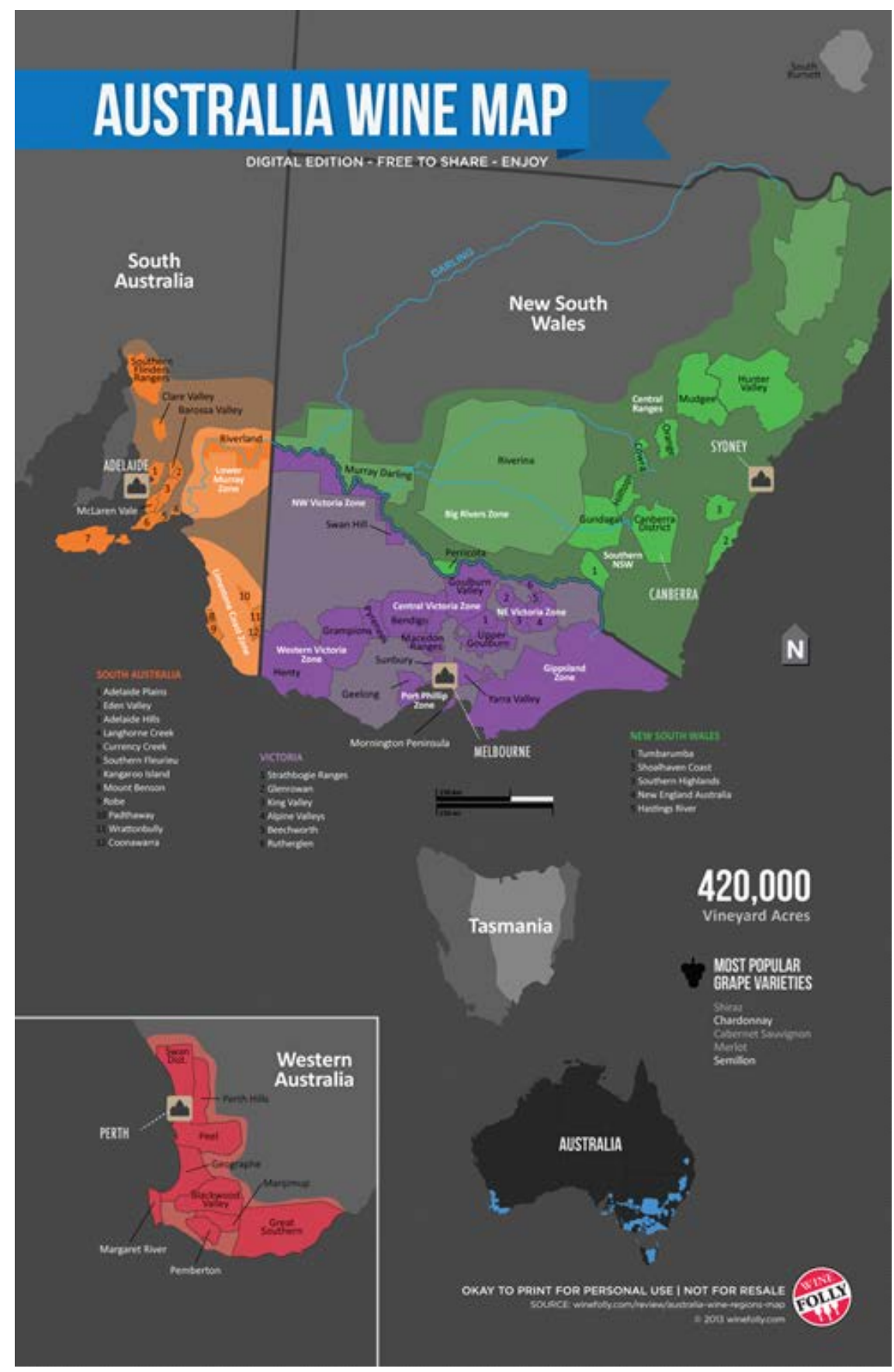

Figure 3: Australian wine regions map. Clare Valley is in orange on the left. Source: Wine Folly, 2014. 
In 1998, the Clare Valley Winemakers Association, the Wine Grape section of the Clare Valley Board of the South Australian Farmers Federation, the Clare Region Wine and Grape Council, as well as five longestablished wineries, jointly prepared an application for GI status under the AWBC Act. These five wineries were Sevenhill, Quelltaler and Leasingham, which were established in 1851, 1868 and 1895 respectively, Knappstein, a winery originally founded by a descendant of one of the region's founding business families, and Taylors, a large winery that only produced its first vintage in 1974, but which today is arguably the region's highest profile producer.

The topographical distinctiveness of the Clare Valley is readily observable (Figure 4). A $300 \mathrm{~m}$ contour forms the western boundary of the Clare Valley GI with Skillogalee Creek bisecting this western boundary and the Clare Valley's 'centre-line.' On the eastern side of the GI, Mount Horrocks, which at 608m is the tallest hill in the region, sits at the head of the Hill River catchment. Near the southern boundary of the GI, Auburn, on the Wakefield River, is at an altitude of 330m. To the west of Clare and Armagh towards the Blyth Plains, vineyards give way to grain cropping areas and sheep farming. A similar transition is evident when travelling east from Clare towards Burra through broad acre (extensive) agricultural land and grazing country.

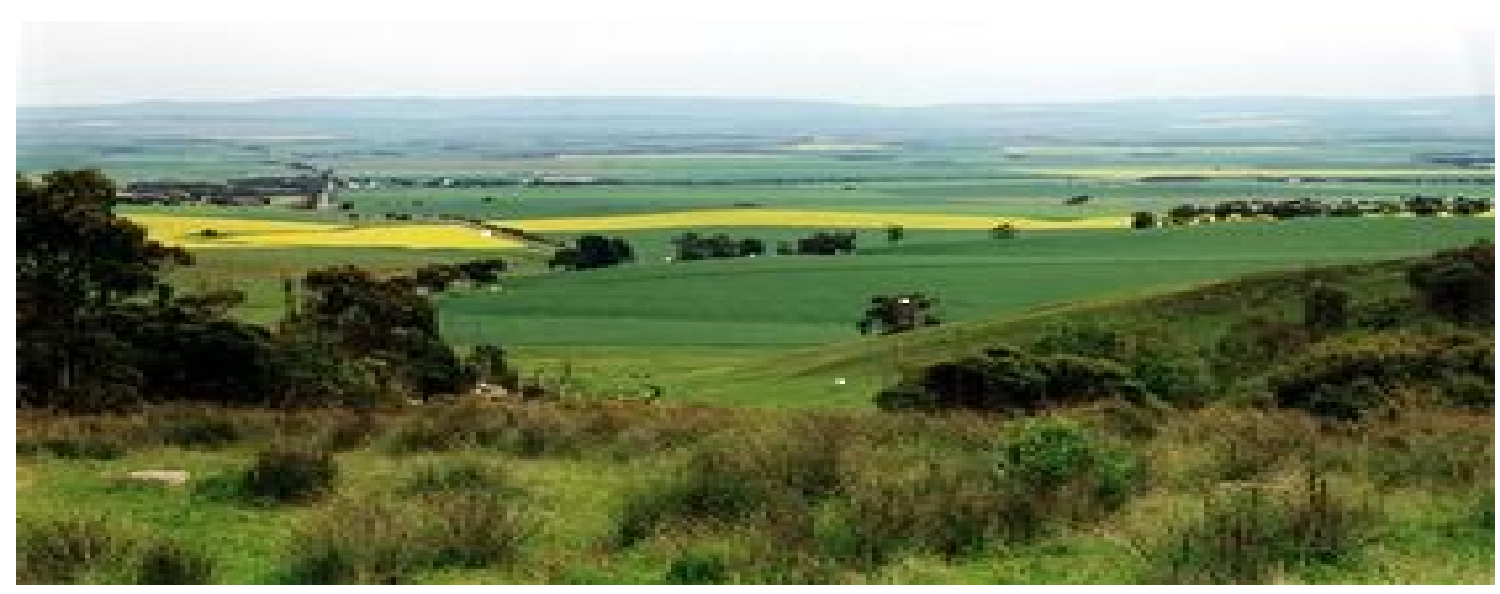

Figure 4: Brooks Lookout (north-western corner of the Clare Valley wine region). Source: TourSA www.toursa.com.au

Given the much-vaunted role of climate in determining the character of grapes and wine (De Orduna 2011), applications for GIs necessarily involve the presentation of data to demonstrate the climatic homogeneity within a region, and distinction from other regions. These attributes include:

...geological formations, climate, harvest dates, natural drainage basins, availability of water for an irrigation scheme, the elevation of the area, plans for development of the area by any authorities, any relevant traditional divisions within the area, and finally, the history of grape and wine production in the area. (Smart 2007: 13)

The application for the Clare Valley GI distinguished Clare from the Barossa, Adelaide Plains and Southern Vales areas through reference to annual isohyets maps. Isohyets are lines on maps that connect places with the same amount of rainfall. The annual isohyet map for $450 \mathrm{~mm}$ showed a strong correlation with maps of the proposed Clare Valley GI. The Mean January Temperature is another key indicator of homogeneity and distinctiveness of a region, as it gives strong indications of the likely timing and character of, the grape ripening process. Harvest data, which in turn is highly dependent on the ripening process that 
climate and weather events dictate, is also a key attribute of a GI, and is typically presented to demonstrate consistency within a region, and difference from other regions. In Clare's GI application, comparisons were made between the harvest dates for three grape varieties in the Clare, Barossa, and Eden Valley regions (Figure 5).

\begin{tabular}{|c|c|c|c|}
\hline Region & Harvest dates (Riesling) & Harvest dates (Shiraz) & $\begin{array}{c}\text { Harvest dates (Cabernet } \\
\text { sauvignon) }\end{array}$ \\
\hline Clare & March 3 & March 8 & March 14 \\
\hline Barossa & March 13 & March 19 & March 25 \\
\hline Eden & April 13 & April 30 & N/A \\
\hline
\end{tabular}

Figure 5: Average harvest dates for the Clare, Barossa and Eden Valleys. ${ }^{8}$

The Clare Valley GI application also included accounts of viticultural practices, including the manual pruning that is performed to moderate cropping levels and to focus water and sunlight on fewer and smaller grape bunches, and which ideally result in an increased concentration of fruit flavours. Other practices included hard-pruning for drought in drier years (where the vine is cut back to below its arms), under-vine jigging, the removal of competing weeds, and contour-banking, where vine rows are planted corresponding to contour lines. The region's irrigation history was also described. Drip irrigation was introduced to the region as recently as 1970, and only expanded in the 1980s with the creation of bores and dams, subsequently increasing the areas available for grape growing. This expansion soon prompted concerns about the sustainability of underground and surface water, resulting in the formal restriction of water use in an area largely contiguous with the Clare Valley GI. ${ }^{9}$ The result has been that irrigation within the Clare Valley has not become a dominant practice, which has had three basic effects: crop levels have been controlled, the volume of vineyard areas has peaked, and less volume, but higher fruit quality has been harvested than in more extensively irrigated areas.

A winemaker who began his career in the Clare region in the early 1980s, well before the region was formally codified, explained how he thought a kind of equilibrium, or limit to the growth of the Clare Valley as a wine region had been arrived at:

Fundamentally ... (the Clare Valley wine region) . . . hasn't changed a heck of a lot. I think we're also constrained really by the natural boundaries that Clare has the topography again, and you get back to the water thing too. Number One: Can you find water on your property? Number Two: Can you get permission to actually take it or look, drill for it? Dams you can't develop any more obviously because there's a moratorium on trapping any more water, not that there's any more water to trap and there hasn't been for a few years. . . I think Clare is, I don't think it'll get much bigger certainly for all those reasons. The key thing is lack of water.

The use of a name was the last issue that the GI application addressed. In 1975 the name 'Clare Valley' was first adopted by district winemakers and the local community at the staging of the Clare Valley Easter Festival; prior to that 'Clare-Watervale' was used as a descriptor. This reflects the fact that prior to expansion from the 1960s and 1970s, wine production was only from wineries within the greater Clare area, and Quelltaler, which was based at the village of Watervale. Thus the term 'Clare-Watervale' covered all the

\footnotetext{
${ }^{8}$ Clare Valley Winemakers Association Inc. (1998).

${ }^{9}$ The primary factor that drove the restriction of water use was the concern about an over-drawing groundwater resources. The salinization of underground water was not identified as a specific problem (CVWA 1998). For more detailed records on salinity levels within the Clare Valley GI see Northern and Yorke Natural Resources Management Board (2009).
} 
winemakers. In 1975 the Clare Valley Winemaker's Association was formed, and this nomenclature has been maintained since.

The distinctiveness of Clare Valley climate patterns compared to nearby wine regions was elaborated clearly, with reference to viticultural practices, harvest data and water use, and the common acceptance of the name 'Clare Valley.' This quest for distinctiveness, though, does not end with the legal codification of the Clare Valley, but rather, begins again, as winemakers seek to achieve further grades of recognition based on smaller and more discrete parcels of land, to cultivate difference and distinction. If, as Moran (1993a: 272) suggests, GIs are opportunities for agricultural communities to try to capture the economic rent of localities and regions, and to create differential rent through demarcating the areas of origin of specific agricultural products, then at what point does this imperative to create distinction cease? The following ethnographic examples demonstrate how the geological and environmental differences within the Clare Valley are perpetually examined and elaborated by winemakers, and how the enterprise of individual producers, their practices, and their wines, and the land they work, have become intricately entwined.

\section{The work of distinction: creating individual value within common regions}

There is general agreement amongst the fifty winemakers and over two hundred grape growers of the Clare Valley region that they themselves constitute a region that can be distinguished from the Barossa Valley to the south and the Riverland regions to the east; the declaration of a GI for the Clare Valley codifies this distinctiveness at a regional level.

However as soon as one travels within the boundaries of the GI more intense attachments to smaller areas become pronounced, as winemakers stress the special character of the areas from which they produce wine. Associations with certain areas such as Watervale and Polish Hill, are keenly and competitively cultivated by various actors within the industry, and become imbued with particular commercial and cultural value.

Premium wine producers invariably reserve a privileged vineyard or discrete area to which painstaking and expensive attention is focused. Much time is spent propagating, maintaining and monitoring the health of these vineyards, in manually pruning and picking batches of grapes from these vines, and in carefully shepherding batches of grapes harvested from these vineyards through the winemaking process. Moreover, the people who own, manage, and work these sites are more deliberate in trying to understand the quality of the relationship between these places and the wines they produce, and they are constantly articulating and elaborating the distinctive character of this relationship. The slow accretion of quality is a constant theme in the way that vineyard sites are named and referred to in colloquial use, and in the newsletters and wine labels that wine producers publish.

All of the 50 Clare Valley wine producers sell at least one wine which is the result of the deliberate selection of a vineyard site, the adaptation of carefully tended vines to vineyard habitats, and fastidious winemaking. For these commercial operators, their practices are centred on sites and procedures much smaller and more specific and refined than the broader physical features and viticultural attributes that characterise the Clare Valley GI. Some winemakers have limited their grape intake to highly discrete patches of land that they own themselves. Other winemakers depend on sourcing grapes from private growers whose vineyards are concentrated in a single area. Still others assert unique or special associations with particular areas through the registration of product names that bear overt references to geographical locations. These different strategies all involve attempts to associate wines and their producers with qualities of authenticity and non-replication that are characteristic of a unique physical site, and which are the basis for a monopolistic relationship.

The exercise of marketing wine is a topic that I address elsewhere, but for the purposes of this article, it needs to be stressed that the genius of marketing the sub-regional or single vineyard wine is in the complex relationship between soil profile, micro-climate, grape variety, cultivation methods, and winemaking practices. These must be posited in such a way that casts winemakers as the revelatory agents of the landscape's latent quality. A brief comparison below of three different wines from five different wine 
producers demonstrates the direct relationship between price and the particularity of a wine's provenance and production process (Figure 6).

\begin{tabular}{|c|c|c|c|}
\hline Category & Brand & Description & $\begin{array}{c}\text { Price } \\
\text { AU\$/US\$ }\end{array}$ \\
\hline \multirow[t]{3}{*}{ Table } & Pikes & $\begin{array}{l}\text { The White Mullet } \\
\text { Vines: sourced from the Clare Valley } \\
\text { Wine: Riesling } 62 \% \text {, Chenin } 18 \% \text {, Sauvignon Blanc } 14 \% \text { and } \\
\text { Viognier } 6 \% \text {. }\end{array}$ & $\$ 12 / \$ 9.2$ \\
\hline & Mitchell & $\begin{array}{l}\text { Riesling wines that are lower priced will typically be sold under a } \\
\text { 'second label', that references the Clare Valley but does not directly } \\
\text { reference the producer }\end{array}$ & N/A \\
\hline & Sevenhill & White wine blend: Riesling/white frontignac & $\$ 12 / \$ 9.2$ \\
\hline \multirow[t]{3}{*}{ Varietal } & Pikes & $\begin{array}{l}2014 \text { Traditionalle Riesling } \\
\text { Vines: } 100 \% \text { Riesling grapes and entirely sourced by the Clare Valley } \\
\text { Wine: the fermentation is inoculated with pure yeast culture, } 100 \% \\
\text { stainless steel, temperature controlled at } 12-15 \text { celsius for } \\
\text { approximately } 25 \text { days }\end{array}$ & $\$ 22 / \$ 16.9$ \\
\hline & Mitchell & $\begin{array}{l}\text { Watervale Riesling } \\
\text { Vines: organically cultivated vineyard }\end{array}$ & $\$ 22 / \$ 16.9$ \\
\hline & Sevenhill & $\begin{array}{l}\text { Inigo Riesling } \\
\text { Vines: Riesling vineyards planted on gently undulating slopes up to } \\
500 \text { metres above sea level. Warm days and cool nights during the } \\
\text { growing and ripening season are perfect for Riesling, as is the } \\
\text { combination of stony and richer, red-loam soils. } \\
\text { Wine: the fruit is gently pressed, taking great care not to allow oxygen } \\
\text { to steal the flavour. The juice is kept very cool and carefully selected } \\
\text { yeasts ferment to dryness at around } 12 \text { degrees Celsius. The individual } \\
\text { vineyard blocks are kept separate until after fermentation when } \\
\text { blending occurs. }\end{array}$ & $\$ 16 / \$ 12.3$ \\
\hline \multirow[t]{3}{*}{ Reserve } & Pikes & $\begin{array}{l}\text { Merle Reserve Riesling } \\
\text { Vines: } 100 \% \text { Single Vineyard Estate grown Polish Hill River fruit } \\
\text { from our Gill's Farm and Hill Blocks. }\end{array}$ & $\$ 36 / \$ 27.7$ \\
\hline & Mitchell & $\begin{array}{l}\text { McNicol Riesling A single vineyard wine, grown on a stony quartzite } \\
\text { hillside at an elevation of 500m. The high elevation means the grapes } \\
\text { ripen } 2 \text { or } 3 \text { weeks later than our Riesling at Watervale. This vineyard } \\
\text { has never been irrigated and no herbicides or pesticides have been } \\
\text { used. }\end{array}$ & $\$ 44 / \$ 33.8$ \\
\hline & Sevenhill & $\begin{array}{l}\text { St Francis Xavier Single Vineyard Riesling } \\
\text { Vines: the } 2014 \text { St Francis Xavier Riesling was produced with fruit } \\
\text { from Weikert Vineyard one of Sevenhill's five Riesling vineyards. This } \\
\text { small vineyard ( } 0.82 \text { ha) was planted in } 1978 \text { and has been recognised } \\
\text { for consistently producing outstanding fruit to meet premium } \\
\text { requirements. } \\
\text { Wine: careful fruit selection ensures that the wine's character is one of } \\
\text { great elegance and varietal authenticity. }\end{array}$ & $\$ 32 / \$ 24.6$ \\
\hline
\end{tabular}

Figure 6: Comparison of wine descriptions and prices. 
Because of this imperative to carve out distinctive spaces for individual wine producers and their wines within the Clare Valley region, the formal definition of areas smaller than the Clare Valley, and the use of names on wine labels that refer to these areas is something that is routinely controversial. Tensions between wine producers striving for distinct identities for their own wines are inevitable, because a significant amount of time, skill, capital, reputation and risk is invested by different winemakers in particular sub-regions. My particular interest here is interrogating the ways in which relationships between wine and particular landscapes are reckoned in the occupational discourse ${ }^{10}$ of winemakers and grape growers in the largest identifiable sub-region within the Clare Valley GI, the Watervale area. Such reckoning is very much the substance of the 'work of distinction' that is critical to the enterprise of fine wine production.

The Watervale area, which is in the central south of the Clare Valley GI, is particularly renowned for its Riesling wines and the very character of this place - wine association is a constant topic in the discourse of winemakers and grape growers. It seems as though everybody has a theory as to why Watervale 'makes' good Rieslings. The distinctiveness of a small region is often characterised in terms of differences in soil. It will often be said by Watervale winemakers and grape growers that Watervale's soil is underpinned by limestone, in contrast and Polish Hill, under which slate, clay and shale are said to sediment. This was clearly borne out to me in interviews and discussions where the question "Why does Watervale make good Rieslings?" was unfailingly regarded as legitimate, and the answers and explanations provided in response were as varied as they were fulsome. In describing the terroir of Watervale, respondents routinely stressed the limestone shield that many described as lying under the region's soil. Limestone is naturally deliquescent and absorbs moisture, so even in dry years vine roots will track underground and penetrate the limestone below the grape vines, and access the moisture embedded there.

One former winemaker, who worked in the Watervale region from the 1950s through to the mid1980s, explained it thus:

The whole of Watervale is on a limestone shield. You can follow it. If you go around the vineyards at Watervale in a dry year you can see vines that are growing on limestone and those that are not.

In a dry year you can tell the vines that are off the shield . . . You know that road that goes from Leasingham out to Mintaro? Down that road going to Mintaro, there's a bloke called Williams. He had a vineyard, probably still has. Half his vineyard was on limestone then it dropped off, and half was not. I reckon it was about 1955, we had a dry year and you could see where the limestone stopped, as easy as anything. That's my theory anyway; I can't see that it's wrong.

Climate was often cited as a factor to explain the quality of Watervale Rieslings, with the 'Port Wakefield Doctor', a colloquial term denoting the south-westerly sea breezes that blow from the north of the Gulf of St Vincent, and moderate the heat of summer. Grape growers and winemakers consistently invoked the particularity of the Watervale region's Riesling grape crops. The importance of this factor was robustly contested by others working in the region, who instead emphasized the lower night-time temperatures as critical to the ability of white grapes such as Riesling to survive hot summers. In turn, others discredited the veracity of this theory by countering that cooler night temperatures apply to the whole of Clare Valley region, thereby offering scant explanation for Watervale's distinctiveness.

Altitude too was referred to when wine and grape producers explained the non-replicability of 'their' wines and grapes. Soils at higher altitude were characterised as 'hungrier', since they only support vines that have the capacity to send their roots deeper in search of moisture and nutrition. Some high-altitude vineyards in the Watervale area produce grapes that are used to make prestigious wines, and these sites are invoked by

${ }^{10}$ In using the term 'discourse' I adopt Peace's definition: "the habitual speech acts and the recurrent conversational subject matters which are prevalent . . . on a daily basis . . . incorporating the recurrent subjects thrown up by the elementary tasks of making a living" (2001: 38-39). 
proponents of this 'altitude theory' in explaining Riesling's success. The differences in altitude across different areas of the Clare Valley GI are small. The highest peak in the GI associated with grape growing, Mt. Horrocks, is only $608 \mathrm{~m}$, while the lowest sections of the GI are around $300 \mathrm{~m}$ above sea level. The fact that such a small difference in altitude is invoked as a significant factor in the distinctiveness of wines produced from differently-sited vineyards indicates how fine-grained, but crucial, these distinctions are for wine producers. Undoubtedly, the importance attributed to altitude as a factor in the production of particular styles and quality of wine grapes and wine is in no way unique to the Clare region. ${ }^{11}$ However, it must be noted that that Clare region winemakers and grape growers theorised about the influence of altitude in order to explain subtle differences within the Clare Valley region, not against other wine regions.

It is instructive that in interviews and conversations recorded with winemakers and grape growers, all agreed that the Watervale area made good Rieslings that could be readily identified as being 'from' Watervale. However, only one informant was prepared to define the area concretely. A "gentlemen's agreement" existed, he explained, that obviated the need for any formal codification of the area:

Watervale has always been a sub-region of Clare. It's not enshrined in law but there's a gentlemen's agreement in terms of how you use it. I can tell you where the area is. The southern boundary of it is half a kilometre from where we are now (just south of Leasingham) and Penwortham bridge is the northern boundary. That's the arc of Watervale - and between one river (Skilly Creek) and the other river (Hill River). It's been well defined.

On the one hand, argument persists about the relative weight that should be accorded to different factors of soil, geology, altitude and climate that ultimately produce Riesling wines from the Watervale area. On the other hand, whilst argument about the relative weight of these different factors persists, no argument exists as to whether or not Watervale can be distinguished from other sub-regions of the Clare Valley. Arguments about what it is that makes Watervale distinctive indeed involves division, but the common interest in being identified with Watervale is far greater than these differences. It was because of this common interest, winemakers and wine grape growers contended that there was a prevailing reluctance to formally define the area. One winemaker who had vineyards within the Watervale area reflected that the recent efforts to establish Watervale as a formal sub-region were met with failure because of resistance from people who were currently selling their grapes to winemakers who produced 'Watervale' labelled wine, but whose vineyards might not be included in a formal description of the area. This opinion may be based on conjecture but nonetheless it refers to the central issue of all the discussion relating to Watervale alluded to above: the value of being associated with the quality of wines that the name conjures. The risk of being ostracised from such an association was keenly felt by many winemakers and grape-growers.

Keys (2006) has documented the discrepancies between the commercial and marketing imperatives that attach to the definition of a wine region, and the actual geographical and climatological specificities of that wine region. The author suggested that these discrepancies hinder the development of sub-regions, despite heterogeneity within designated wine regions. He attributes this partly to the relative paucity of geographic and climatological expertise that is deployed in determining (at a formal regulatory level) to what extent geographical areas are legitimate wine regions. This suggests, though, that there is a consensus as to the precise ways in which environmental factors such as soil, geology, altitude, climate, and grape clones manifest in the perceived quality of the wine. Among those actually producing the grapes and the wine, the ways in which these qualities are made manifest in identifiable qualities of wine is a perpetual topic of conversation, argument and theorisation. In relation to the Watervale region these discussions are commonplace, and are informed by detailed and long-earned understandings of the uniqueness of vineyard sites.

\footnotetext{
${ }^{11}$ See Chang et al. (2007) for a discussion of altitude in the New England (Australia) region. For broader discussion of the role of altitude in viticulture in the context of a changing climate see Anderson (2008).
} 
The genius of the locally produced fine wine is to express and capture the distinctive terroir of a particular local area, and for the wine produced from this area to reflect the complex interaction between soil, climate, topography, and the viticultural and winemaking techniques that are applied to the vineyards and grapes produced in these areas. Winemakers often cast themselves as acting to give voice to the otherwise muted significance of the relationship between these factors. The tension that is inherent in this role, where a winemaker claims to be at once reflecting existing properties, and an alchemist synthesising these properties in novel forms, attracts respect and scepticism, summed up in a joke that is often told within the industry:

"Q: What's the difference between God and a winemaker? A: God never claimed to be a winemaker."

A winemaker who made wines in the early 1970s from the Quelltaler estate, the Watervale area's oldest vineyard site, recounted to me the readiness with which he could distinguish the wines from adjacent vineyards. His reflections highlight the acute sensitivity that some winemakers and grape growers develop to the nuances of each site. Some areas, though, seem to defy such typification, and particular reverence was reserved for these:

DR: Watervale is a good Riesling region. Do you have an idea as to why that's the case?

Not really, it was quite interesting because at Quelltaler the maximum size old oak cask that we had was 500 gallons. We could have 30 to 40 of these casks. You used to put the samples out after vintage for tasting, and we had individual vineyards all over the place. Every different one was distinctive. When I was there I could pick eight or nine of the top vineyards just by going through and going: "that's that, this is that", just from a quick taste.

The best one that we had was called Carl's Field. It was distinctive every year. That vineyard was named after Carl Sobels. It was just clay and slate shale all over the hill. They'd done soil tests and there's no reason apparently, why the Riesling was so distinctive off that hill. That was always our top line. We used to bottle 1,000 gallons of the best of that. The rest of it used to go into the normal Riesling line. Carl's Field, there was 1,000 gallons from there in the bottle. They used to be held for up to three or four years, people could never get enough of it. We put it on the market and weeks later it would be gone.

This professed ignorance as to precise understandings of the relationship between vineyard site and wine character does not signal a mistrust or under-estimation of the contribution that geology, altitude and climate make to the quality of wines produced from particular sites. Rather, I think it is better understood as a measured acknowledgment of the inevitable variation that is apparent even in areas very close to each other. Understandings of the relationships between terroir and wine might be better thought of, then, not as definitive statements of ecological dynamics but as occupational tools of understanding and communication whose application is constantly revised by those growing grapes and making wine. This is well expressed by another winemaker whose livelihood depended on continuing to make premium Riesling wines from each year from the Watervale area. His comparison of two different vineyards in the Watervale region underscores the constant refinement and revision of understandings of the relationship between place and product:

DR: Why is Watervale Riesling different from Polish Hill Riesling?

It's the interaction of a whole lot of factors. Personally, I think that soil is the most significant factor. At Grower's block it's got a deeper topsoil than say Alcatraz, very similar composition, brown loam over limestone, but the loam is deeper at Grower's, the brown stuff is deeper. So there's more ability for the roots to penetrate and get greater nutrition - there's a greater nutrition bank in that soil. So the flavours are bigger at Grower's. We call it the Mike Tyson of 
our vineyards - it's bigger. Whereas at Alcatraz it's more like a Muhammad Ali; more elegant but still with power. With shallower topsoil, the vines struggle a little bit more. If a wine has a got a stronger, bolder flavour, we might say it's got more pixels.

There's very little research on this stuff. Because of the complexity of the interaction of vine, root, soil, the whole soil profile, not just the topsoil - these things all interact. It's really impossible to come up with a proper scientific explanation of how we relate soil to wine. The wine industry has always talked about it: this vineyard produces this flavour because of this soil, but the interaction is so complex.

A lot of it is just based on experience. We grasp at things. We have a vineyard just over the back of the hill at Grower's, and the vines are growing on soils that have a much slatier subsurface. The wines taste minerally, slatey. So you're connecting a place to a taste. It's not a scientific exercise, saying that the slate produces a minerality - say that to a soil scientist they roll their eyes and say: "you can't connect things that simply." But it's really just a tool for us to explain it to ourselves. The old timers will say, this is flavoured like this because of this, and they will dogmatically connect the two, but the boffins would roll their eyes.

From this ethnographic evidence, the terroir concept is shown to sit comfortably with wine producers in the Clare Valley because it is not seem as dominated by environmental determinism (Moran 1993b), and that terroir's application to Australian conditions actually promotes the entry, and pursuit of distinction on the part of wine producers. For producers such as those of the Clare Valley, the chief reference against which distinction is sought is the larger-scale producers from highly irrigated regions who produce high volumes of generic wine, which is typically sold with scant reference to the source of the wine grapes that are crushed to make it. Reliability, consistency, and a lack of variability are the hallmarks of such products. But for winemakers and grape growers from a region such as the Clare Valley, the concept of terroir is consistent with the genuine preoccupation with perpetually theorizing the relationships between a range of ecological, viticultural and oenological factors that are critical to their business enterprise. One winemaker described the irrigated wine producers on the Riverland region to the north-east of the Clare Valley as "great exporters of water." In the struggle to obtain greater recognition of distinctive local wines that are tied indelibly to discrete places, this winemakers clearly saw the struggle as being against these larger-scale Australian producers.

The way that winemakers and grape growers think and talk about these relationships at an everyday level, and how this informs their approach to planting, pruning and picking grapes, and making wine, is critical to the creation of the distinctive viticultural landscape of the Clare Valley region. There are efforts to claim monopolistic or privileged relationships to land, but this monopolistic imperative is always restrained. This is because if land has to be constructed as the ultimate source of the value that inheres in a wine and the winemaker and the grape grower is the means by which this latent, immanent value is realised, then the value of an area of land cannot be denied to any other tenant or owner of it. To deny this egalitarian opportunity to others would be to deny the possibility of the creative act of composing original wines, something that a premium wine producer would not wish to deny for themselves. A degree of latitude has to be retained for the creative act of wine production. If a wine is only the reflection of static factors, then a wine producer must forfeit any role of authorship or composition. It is rewarding to Watervale winemakers and grape growers, then, to tacitly agree to define the Watervale area as distinctive from other Clare regions, but to limit this prescription.

This debate about wine regions and sub-regions that those in the wine industry consistently participate in, and the business strategies that different Clare producers employ towards marketing the geographical source of their wines, reflects a strategic equivocation that accompanies the pursuit of very particular commercial relationships within wider wine markets. Winemakers are attempting to keep a commercially fatal bind at bay: the risk of a product's distinctiveness being lost or diluted in the pursuit of market recognition. It is for this reason that an egalitarianism that emphasises the distinctiveness that an individual 
wine or grape grower must rent from the prevailing habitat, is a dominant ideology. This ideology, I contend, is the principal explanation for why wine regions remain the numerically dominant category of GI, despite the heterogeneity within these regions.

Harvey (2002) draws a sharp distinction between taste and terroir as a basis for formulating the commercial value of wines. He cites the influence of American wine writer Robert Parker ${ }^{12}$ in fostering this distinction, due largely to the wine scoring system that Parker has popularised that evaluates only the taste of the wine. The popularity of this methodology is complemented by a burgeoning vocabulary dedicated to describing a wine's taste. Much of this description is figurative, in that it does not attempt to list a wine's component ingredients, but tries to equate it with tastes to which some likeness can be drawn, with wines often characterized as having 'hints of lemongrass' or 'peach overtones.' This discursive shift, Harvey argues, works to undermine the monopoly claims that wines producers can make, because, ostensibly, wines from anywhere can achieve the same scores on Parker's system and receive the same descriptions.

This alleged dichotomy between taste, which is constructed discursively, and terroir, which has inescapable physical and ecological properties, is unfounded. Winemakers and grape growers in the Clare Valley region are constantly trying to better understand the relationship between specific places and the wine that is produced from them, and the language of wine tasting that Parker and others have popularised is another tool recruited to this task. Importantly, these rhetorical tools and resources are directed towards describing one's own wines, an act which also works to distinguish one local wine from another. Talking about, thinking about, and arguing about how the character of particular areas is related to wine are not discursive actions only. Irvine (1989) contended that the dichotomy between language and political economy is a false one, and that a materiality should be accorded to the way that people talk, and what they talk of. This is particularly so in the instance of taste in wines, where the physical exercise of tasting wines needs to be transformed into concrete understandings, and commercial relationships, for production of fine wines to be sustained. I make brief reference here to some particular marketing strategies to elaborate on this challenge.

It is instructive that the wineries in the Clare Valley that are most successful in producing wines that are recognised and sold as fine wines, and that always attract a demand much higher than their supply, allow little access to the public. In short, it is hard to buy their wines. Two particular wineries are a case in point. Wendouree Cellars and Grosset Wines have wines listed in Langton's 'Exceptional' category, the highest class of Australian wine that currently admits seventeen wines. Such a listing guarantees high auction prices, and ensures a high demand for the listed wines. In addition, specialist bottle shops (liquor stores) and prestigious restaurants will want to stock these wines, and they will often be bought for special domestic events. The demand for wines ranked in this category, and any of the other classifications that Langton administer, will always be higher than their potential supply. This is because these wines are produced from discrete, nonexpandable parcels of land, and are the result of the highest available order of human attention to the grape growing and winemaking process. These winemakers and others who produce such highly ranked wines do not compromise on the methods used to produce their wines, and make wine only if the fruit harvested each year is of sufficient standard. Some years, these wines are not produced.

Mailing lists, through which customers can order wine, are limited at these wineries, and there are substantial waiting times to get on to them. Grosset Wines open for only five days a week for six weeks each year, if stocks last that long. Wendouree are not open to the public at all. Grosset Wines run a website ${ }^{13}$, but it offers little in the way of practical details that would assist a potential buyer, instead concentrating on other items of interest to dedicated wine buyers. Wendouree have neither website nor any computer-based communication with customers. ${ }^{14}$ These wineries are in a position which allows them to permanently limit production, sell all their wine, and retain lucrative, small-scale trade with a limited number of customers.

\footnotetext{
${ }^{12}$ See Langewiesche (2000) for a summary of Parker's influence on the wine industry.

13 https://www.grosset.com.au

14 https://www.ozwinereview.com/2015/12/a-visit-to-wendouree-the-most-surprising-cult-winery-in-the-country.html
} 
And, in doing so, they are able to cultivate a growing demand and interest in their wines from people who would like to buy them, or buy them more often.

\section{Conclusion}

In his ethnography of the Medoc and Dordogne regions of south-western France, Ulin (1996: 8) explained that the relationships between vineyard sites, grape growers, winemakers and wine has become so well constructed, so closely enmeshed, and so regularly elaborated, that these social relationships are cast as natural, and their natural character is underwritten by and expressed through science and its viticultural, geological and hydrological orthodoxies. These very relationships between vineyard sites, soil types, geological formations and the quality of the wine is conveniently, and confusingly expressed in the French term terroir, for which there is no ready English translation.

Making wines whose grapes are drawn from a specific territory is but one requirement in entering the register of quality wine production and circulation. The other key aspect of entering such a realm of circulation, which in itself reinforces the land-centred complex of quality-focused practices involved in making grapes and wine long ago identified by Marx (1967: 774-775), is to consciously identify the provenance and the underlying craft of such wines. To register wines as unique, through reference to territorial markers is the accomplishment that winemakers are seeking; to make their wines marketable, recognisable and distinctive.

Globalization of particular place names and their associated artisanal-based principles counters the standardization of products which is normally considered the outcome of the internationalization of the agrofood industries (Moran 1993a: 265). In this sense, it does present an avenue of value-creation that is glossed as the 'quality turn' in agriculture (Goodman 2004). In Australia, the AWBC Act 1980 and its mandate to create wine regions, and protect the use of their names, provides an instrumental basis for the producers of premium wine, many of whom are small, family-based businesses, to resist the industrialization and corporatization of generic wine production that is dominated by the "supermarket oligopolies" (Croser 2006: 14).

The very character of the dynamic relationship between these factors is constantly posited, theorised and debated in the realms of wine marketing and consumption, where journalists, retailers, connoisseurs and consumers are constantly evaluating, judging and making distinctions between wines and styles. Silverstein describes this critical apparatus that has emerged around the wine industry as a "multicomponential lexicography" (2006: 481) that can encompass these diverse social and spatial realms of production, connoisseurship and distribution, where knowledge and power is unevenly distributed, but remains squarely focused on particular objects.

Morris, in his study of the Mendoza wine region of Argentina noted that despite the integration of local viticultural landscapes with international wine economies, because of the wine grape's acute vulnerability to seasonal variation, the industry cannot be subject to the same kind of external control that determines yields and supply chains in other industrialized agricultural settings such as raising pigs or battery-fed hens (2000: 152). ${ }^{15}$ This ethnographic intervention makes problematic Frow's (1997) oft-cited distinction between the discovery of natural processes, on the one hand, and the development and application of industrial technologies to these natural processes on the other, as representing a monopolistic form of commodification. Such a distinction is unable to fully consider the temporal, seasonal component that is fundamental to grape-growing and winemaking, and on which the commercial distinctiveness that is so sought by wine producers rests: the slow accretion of very local experience related to viticulture, the vinification of the grapes that follows viticulture, and the incremental, sometimes ad hoc cultivation of markets of consumers through personal and word-of mouth contact. In the so-called Old World of wine producers, notably France, Germany, Italy and Spain, these processes have had centuries upon centuries to

\footnotetext{
${ }^{15}$ For ethnographic analyses that provide "local, temporal, and sectoral diversions" (Walker 1997: 277) to mechanical interpretations of global capitalist accumulation in agriculture, see Boyd and Watts (1997) on chicken farming, Page (1997) for the pork industry and Wells (1997) for strawberry farming.
} 
develop, and the efforts of the Appellation d'Origine Contrôlée in France, for instance, are geared to evaluating, and calibrating the balance between human and non-human terroir that must constantly be struck and which ultimately ensure that no two wines can be alike.

In Australia, where wines and wine regions are comparatively under-regulated compared to France, wine producers who market generic, non-regional wine are not limited to particular wine regions when sourcing grapes, and this is an important hedge against inevitable instability in yields in any single region from season to season. However, for all but a very few of the Clare region's winemakers, commercial success is tied tightly to the Clare region, and smaller areas within it, such as Watervale, the geographic focus of this article. The association with these areas is highly prized, and any perceived threat to the recognisable distinctiveness that flows from these associations is a cause of considerable anxiety.

In the Clare Valley wine region, a rich occupational discourse has evolved that grape growers and winemakers employ to understand these distinctive environmental and topographical attributes that their work is ideally being seen to realize. This discourse, with its nuanced insights into the characteristics of discrete patches of land, is a form of commercial resilience, and a hedge against inevitable macro-economic instability, as well as chronic shortages of water and arable land. Wine producers make an egalitarian accommodation to each other by claiming unique abilities to transform the environmental properties of land into distinctive products, but they stop short of claiming a monopolistic privilege over the ability to fashion such particularity from land. This is hard-won social infrastructure. This land-focused discourse, which is constantly in tension, reflects an acute sensitivity to the livelihoods of peer producers. It is these social technologies that provide an alternative to the 'race to the bottom' that is large-scale wine production in Australia, and which is antithetical to pursuit of quality production that itself has become ubiquitous within the wine industry (Aylward 2006: 17).

Within agro-sociological scholarship, the consumer 'turn' (FitzSimmons and Goodman 1998; Urry 1995) within the agricultural sector is synonymous with a growing demand for food and drink whose provenance, process of production, and environmental footprint is readily identifiable. Of particular relevance to the premium wine industry is DeLind's (1993) description of 'niche' markets as a means of hedging against the vulnerability that is endemic to agricultural markets:

The vulnerability in a single commodity may be offset by expanding the forms of control over such things as genetic diversity, product variation and identification, and the integration of production and marketing processes. (DeLind 1993: 8)

Nonetheless DeLind is sceptical of the extent to which the niche market, as a commercial strategy, can be harnessed by agricultural producers for their own benefit, and contends that niche markets effectively efface the social dimensions of agricultural sustainability and are a further extension of capitalist agriculture, where the value of product differentiation is a privatized commercial asset. It is difficult to dispute the applicability of this analysis to the Australian premium wine industry, where difference and distinction is a commercial imperative. But these values of distinctiveness are not only commercial. The social technologies that provide for this commercial value to accrue, being the egalitarian accommodations that winemakers and grape growers make to each other through their own perpetual commitment to understanding the relationship between what they produce and the land from which it is produced, are highly pragmatic adaptations to a physical habitat that is decidedly non-reciprocal, as John Bennett long ago recognised:

In dealing with climate or soil, one takes what is there, or what one gets, and does the best one can with it: one takes a chance, or tries to enhance or conserve the supply. Consequently, adaptation to the environment is an internal or one-sided action; it does not involve reciprocity. (1968: 452) 
The legal and policy instruments of GIs have played a significant role in such adaptations by enforcing an alignment of local producers with local resources, and by creating a form of intellectual property out of regional landscapes. In the absence of external inputs such as assured irrigated water, it is only prudent to think that Australian agriculture will be forced to make further adaptations to a nonreciprocal environment, and produce more economic value from less environmental resources (Hardisty 2010). But for the Australian wine industry to survive in such a scenario such adaptations will need to be performed in the concrete physical and discursive domains in which premium wine enterprises operate. Understanding just how these adaptations are, or are not achieved at the concrete level, is a challenge that ethnography is only uniquely positioned to, and indeed must meet, if the ever-present calls to 'add value' to Australian agriculture are heeded.

Market access alone will not guarantee an increased return in value for Australian premium wine producers, constrained as they are by environmental factors, and given their disposition to the deliberate cultivation of distinction in production. The commitment to distinction is a struggle that will continue to be enacted at the vineyard, winery and point-of-sale level, and will be where many livelihoods are won and lost. This fact alone justifies our ongoing ethnographic attention.

\section{References}

Australian Bureau of Statistics. 2012. Australian wine and grape industry, 2010-2011. [Retrieved 22 May 2012]. www.abs.gov.au

Allen, M. 2010. The future makers: Australian wines for the $21^{\text {st }}$ century. Melbourne: Hardie Grant.

Alston, M. 2004. "Who is down on the farm?" Social aspects of Australian agriculture in the 21st century. Agriculture and Human Values 21(1): 37-46.

Anderson, K. 2003. Wine's new world. Foreign Policy 146: 46-54. http://www.jstor.org/stable/3183622

Anderson, K., C. Findlay, S. Fuentes and S. Tyerman. 2008 Viticulture, wine and climate change. Garnaut Climate Change Review 01-16.

Askew, L. and M. Sherval. 2012. Short-term emergency or recurring climatic extreme: a rural town perspective on drought policy and programs. Australian Journal of Public Administration 71(3): 290302. Researchgate

Aylward, D. 2006. Innovation lock-in: unlocking research and development path dependency in the Australian wine industry. Strategic Change 15 (7-8): 361-372.

Aylward, D. 2008. Towards a cultural economy paradigm for the Australian wine industry. Prometheus 26 (4): 373-385.

Aylward, D. 2010. Moving from creative to cultural industries: the case of the Australian wine sector. International Journal of Business and Globalisation 5(2): 135-146.

Banks, G, S. Kelly, N. Lewis and S. Sharpe. 2007. Place 'From One Glance': the use of place in the marketing of New Zealand and Australian wines. Australian Geographer 38(1): 15-35. Researchgate

Banks, G. and S. Sharpe. 2006. Wine, regions and the geographic imperative: the Coonawarra example. New Zealand Geographer 62: 173-184.

Barham, E. 2003. Translating terroir: the global challenge of French AOC labelling. Journal of Rural Studies 19: $127-138$.

Barlett, P.F. (Ed). 1980. Agricultural decision making: anthropological contributions to rural development. New York: Academic Press.

Bennett, J. 1968. Microcosm-macrocosm relationships in North American agrarian society. American Anthropologist 69: 441-454.

Bennett, J. 1969. Northern plainsmen: adaptive strategy and agrarian life. Chicago: Aldine.

Bjørkhaug, H. and C. Richards. 2008. Multifunctional agriculture in policy and practice? A comparative analysis of Norway and Australia. Journal of Rural Studies 24(1): 98-111. 
Black, R. 1990. 'Regional political ecology' in theory and practice: a case study from Northern Portugal. Transactions of the Institute of British Geographers 15 (1): 35-47.

Black, R. and R. Ulin (eds.). 2013. Wine and culture: vineyard to glass. London: Bloomsbury.

Botterill, L. and D. Wilhite. (eds.). 2005. From disaster response to risk management. Dordrecht: Springer.

Chang, H., G. Campbell and P. Sniekers. 2007. Geographical indication for New England wines in NSW. 51st AARES Annual Conference.

Clare Valley Winemakers Association Inc. Clare Valley Board of the SA Farmers Federation, and Clare Region Wine and Grape Council. 1998. Geographical indication application for Clare Valley, South Australia. Clare, South Australia .

Cocklin, C. and J. Dibden (eds.). 2005. Sustainability and change in rural Australia. Sydney: UNSW Press.

Commonwealth of Australia. 2012. Water Act 2007 (Basin Plan). Canberra: Murray-Darling Basin Authority.

Cox, J. and L. Bridwell. 2007. Australian companies using globalization to disrupt the ancient wine industry. Competitiveness Review: An International Business Journal 17(4): 209-221.

Croser, B. 2006. The Australian fine wine industry, irrelevant or neglected? The Australian and New Zealand Wine Industry Journal (November/December): 16-20.

DeLind, L. 1993. Market niches, 'cul de sacs', and social context: alternative systems of food production. Culture and Agriculture 47: 7-12.

Demossier, M. 2011. Beyond terroir: territorial construction, hegemonic discourses, and French wine culture. Journal of the Royal Anthropological Society 17: 685-705.

De Orduna, R. 2010. Climate change associated effects on grape and wine quality and production. Food Research International 43(7): 1844-1855.

Diamond, J. 2005. Collapse: how societies choose to fail or survive. Camberwell: Penguin.

Edmond, G. 2006. Disorder with law: determining the geographical indication for the Coonawarra wine region. Adelaide Law Review 27: 59-182.

Elden, S. 2010. Land, terrain, territory. Progress in Human Geography 34(6): 799-817.

Fitzsimmons, M. and D. Goodman. 1998. Incorporating nature: environmental narratives and the reproduction of food. In Braun, B and N. Castree (eds.) Remaking reality: nature at the millennium. London: Routledge.

Flannery, T. 2008. The weather makers: the history and future impact of climate change. Melbourne: Text.

Frow, J. 1997. Time and commodity culture: essays in cultural theory and postmodernity. Oxford: Clarendon Press.

Garcia-Parpet, M.-F. 2008. Market, prices and symbolic value: grand crus and the challenges of global markets. International Review of Sociology 18 (2): 237-252.

Garnaut, R. 2008. The Garnaut climate change review: final report. Cambridge: Cambridge University Press.

Goodman, D. 2003. The quality 'turn' and alternative food practices: reflections and agenda. Journal of Rural Studies 19 (1): 1-7.

Goodman, D. 2004. Rural Europe redux? Reflections on alternative agrofood networks and paradigm. Sociologia Ruralis 44 (1): 3-14.

Goody, J. 1982. Cooking, cuisine and class: a study in comparative sociology. Cambridge: Cambridge University Press.

Gordon, W. 2004. A survey of wine grape producers in the Clare and Victoria Murray Valley regions 200203. Canberra: Grape and Wine Research Development Corporation.

Gray, J. 1996. Family farms in the Scottish borders: a practical definition by hill sheep farmers. Journal of Rural Studies 14 (3): 341-356. 
Gray, J. 2009. Rurality and rural space: the 'policy effect' of the Common Agricultural Policy in the Borders of Scotland. In F. Merlan and D. Raftery (eds.) Tracking rural change: community, policy and technology in Australia, New Zealand and Europe. Canberra: Australian National University E Press. Pp.15-39.

Gray, I. and G. Lawrence. 2001. The future of regional Australia: escaping global misfortune. Cambridge, Cambridge University Press.

Halliday, J. 2007a. Crushing news, with worse ahead. The Weekend Australian. Sydney: News Limited.

Halliday, J. 2007b. Growing challenges as the game constantly changes. The Weekend Australian. Sydney: News Limited.

Halliday, J. and H. Johnson. 1992. The art and science of wine. London: Mitchell Beazley.

Hardisty, P. 2010. Environmental and economic sustainability. New York: CRC Press.

Harvey, D. 1982. The limits to capital. Oxford: Basil Blackwell.

Harvey, D. 1989. The condition of post-modernity. Oxford: Basil Blackwell.

Harvey, D. 2002. The art of rent: globalization, monopoly and the commodification of culture. Socialist Register 38: 93-110.

Head, L. 1999. The northern myth revisited? Aborigines, environment and agriculture in the Ord River Irrigation Scheme, Stages One and Two. Australian Geographer 30(2): 141-158.

Heller, C. 2006. Post-industrial "quality" agricultural discourse: techniques of governance and resistance in the French debate over GM crops. Social Anthropology 14 (3): 319-334.

Hunt, W, C, Birch, J, Coutts and F. Vanclay. 2012. The many turnings of agricultural extension in Australia. The Journal of Agricultural Education and Extension 18(1): 9-26. Academia

Irvine, J. 1989. "When talk isn't cheap": language and political economy. American Ethnologist 16(2): 24867.

Keys, T. 2006. Testing the 'homogeneity' of Australia's GIs. The Australian and New Zealand Wine Industry Journal 21(6): 83-85.

Langwiesche, W. 2000. The million dollar nose. Atlantic Monthly 286 (6): 11-22.

Lawrence, G. and F. Vanclay. 1995. The environmental imperative: eco-social concerns for Australian agriculture. Rockhampton: Central Queensland University Press.

Lawrence, G. and F. Vanclay. 1994. Agricultural change in the semiperiphery: the Murray Darling Basin, Australia. In P. McMichael (ed.) The global restructuring of agro-food systems. Ithaca: Cornell University Press.

Lawrence, G. 1987. Capitalism and the countryside: the rural crisis in Australia. Sydney: Pluto Press.

Lockie, S. and L. Bourke (eds.). 2001. Rurality bites. Annandale: Pluto Press.

Lofts, G. 2010. Heart and soul: Australia's first families of wine. Milton: Wiley.

Marsh, S. and D. Pannell. 2000. Agricultural extension policy in Australia: the good, the bad and the misguided. Australian Journal of Agricultural and Resource Economics 44(4): 605-627.

Marx, K. 1967. Capital: volume 3. New York: International Publishers.

Mattinson, C. 2007. Why the French hate us: the fight to save Australian wine. Melbourne: Hardie Grant.

Merlan, F. and D. Raftery. 2009. Introduction: the rural future in Australia and New Zealand: mapping the terrain of rural change. In Merlan, F. and D. Raftery (eds.) Tracking rural change: community, policy and technology in Australia, New Zealand and Europe. Canberra: Australian National University E Press.

Mesiti, L. and F. Vanclay. 1996. Farming styles amongst grape growers of the Sunraysia district. In G. Lawrence, K. Lyons and S. Momtaz (eds.) Social change in rural Australia. Rockhampton: Rural Social and Economic Research Centre, Central Queensland University. Pp. 38-54.

Moran, W. 1993a. Rural space as intellectual property. Political Geography 12(3): 263-277. 
Moran, W. 1993b. The wine appellation as territory in France and California. Annals of the Association of American Geographers 83(4): 694-717.

Morgan, K, T. Marsden, and J. Murdoch. 2008. Worlds of food: Place, power, and provenance in the food chain. Oxford: Oxford University Press.

Netting, R.M. 1974. Agrarian ecology. Annual Review of Anthropology 3: 21-56.

Northern and Yorke Natural Resources Management Board. 2009. Water allocation plan for the Clare Valley Prescribed Water Resources Area. Crystal Brook: Government of South Australia.

Peace, A. 2001. A world of fine difference: the social architecture of a modern Irish village. Dublin: University College Dublin Press.

Perry, M, R. Le Heron, D. Hayward and I. Cooper. 1997. Growing discipline through total quality management in a New Zealand horticulture region. Journal of Rural Studies 13(3): 289-304.

Polanyi, K. 1957 (1944). The great transformation. New York: Rinehart.

Pritchard, B. 1999. The regulation of grower-processor relations: a case study from the Australian wine industry. Sociologia Ruralis 39(2): 185-200.

Rabobank. 2015. Premium wine: it's a long way to the top. Rabobank Industry Note 473.

Rainer, G. 2016a. The making of the 'world's highest wine region': globalization and viticulture restructuring in Salta (NW Argentina). Erkunde 70(3): 255-269.

Rainer, G. 2016b. Constructing globalized spaces of tourism and leisure: political ecologies of the Salta Wine Route (NW-Argentina). Journal of Rural Studies 43: 104-117.

Remaud, H. and J-P. Couderc. 2006. Wine business practices: a new versus old wine world perspective. Agribusiness 22: 405-416.

Sheales, T, S. Apted, A. Dickson, R. Kendall and S. French. 2006. Australian wine industry: challenges for the future. Canberra: Australian Bureau of Agricultural and Resource Economics.

Silverstein, M. 2006. Old wine, new ethnographic lexicography. Annual Review of Anthropology 35: 481496.

Simon, A. 1966. The wines, vineyards, and vignerons of Australia. Melbourne: Lansdowne Press.

Smart, R. 2007. Australia's GIs: is the approach rational? The Australian and New Zealand Wine Industry Journal 22(2): 13-17.

Soosay, C. and A. Fearne. 2011. Using Sustainable Value Chain Analysis as a catalyst for co-innovation in regional development: a case study of South Australian wine from the Riverland. International Journal of Innovation and Regional Development 3(2):126-140.

Song Yoon, S.Y. 1975. Provençal wine cooperatives. In J. Boissevain and J. Friedl (eds.) Beyond the community: social process in Europe. The Hague: Department of Education for the Euromed Study Group.

Stinner, B. and G. House. 1987. Role of ecology in lower-input, sustainable agriculture: an introduction. American Journal of Alternative Agriculture 2(4): 146-147.

Ulin, R.C. 1996. Vintages and traditions: an ethnohistory of southwest French wine cooperatives. Washington: Smithsonian Institution Press.

Ulin, R.C. 2002. Work as cultural production: labour and self-identity among southwest French winegrowers. Journal of the Royal Anthropological Institute 8: 691-712.

Unwin, T. 1996. The wine and the vine: a historical geography of viticulture and the wine trade. London: Routledge.

Urry, J. 1995. Consuming places. New York: Routledge.

Warner, K.D. 2007a. The quality of sustainability: agroecological partnerships and the geographic branding of California winegrapes. Journal of Rural Studies 23: 142-155. 
Warner, K.D. 2007b. Agroecology in action: extending alternative agriculture through social networks. Cambridge, MA: MIT Press.

Watts, M.J. 2000. Political ecology. In Barnes, T.J. and E.Sheppard (eds.). A companion to economic geography. London: Wiley/Blackwell. Pp. 257-274.

Williams, R. 1976. Keywords: a vocabulary of culture and society. New York: Oxford University Press.

Wilson, J.E. 1998. Terroir: the role of geology, climate, and culture in the making of French wines. London: Mitchell Beazley.

Whittington, E. 1997 [1903]. The South Australian vintage 1903. Adelaide: Friends of the State Library of South Australia.

Wine Australia. 2007. Directions to 2025: an industry strategy for sustainable success. Adelaide: Australian Wine and Brandy Corporation and Winemakers Federation of Australia.

Wine Australia. 2015. Wine Australia website. [accessed 12 November 2015] www.wineaustralia.com

Wine Australia 2016. State of Australian wine: results of the 2015 wine production, inventory and domestic sales survey. Wine Australia website. [accessed September 15 2016]. www.wineaustralia.com

Winemakers Federation of Australia. 1996. Strategy 2025: the Australian wine industry. Adelaide: Winemakers' Federation of Australia.

Wine Folly, 2014. Australia wine map. http://winefolly.com accessed 1 November 2016. 